p. 236

体有学

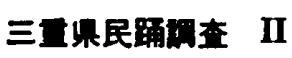

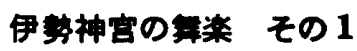

1. 经类の原史

三重大学岡田久江

舞楽は雅楽を伴奏として行ら舞踊のことで我が国古来 の様式に基くものと，外来楽の様式に基くものと 2 価に 分けられる。

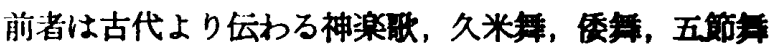
東遊などであり，後者は网陵王，㘨曾利など凡そ 1500 年程前フジフ大陸より伝来栈多の興亡を経て今日まで伝 承して来たものである．即ち 允恭天皇崩御（453）に新 羅より楽人 80 人が渡来し新再楽を奏したのを外来楽の 始めとし，続いて推古天皇の代に百清の味摩之が器化し て伎楽を伝え，又大陸と交通が開けてからは直接音楽や 舞踊などが伝来するよらになり唐楽, 溯海楽が伝わり， 天平年間には林邑の僧仏哲により林芭楽が，天然の僧萻 提により印度楽が伝わつた. 又雅樂案などの設固により 内外の音楽の統轄伝習に努め大結果奈良末期から平安切 期にかけては我が国です新作が生れ更に隆盛になつた。 この頃舞楽は宮中の宾会などで行われた外神社や寺院の 祭典法要にも演奏され東大寺など大和地力は特に盛大で あつた。このよらに盛大になつた外来楽す曲目の增加に つれ混沌とした為に平安中期に至つて 整理大鞂革を行

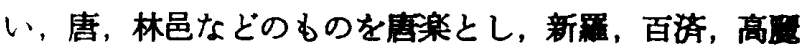
など朝鮮半島を経由して层したるの及び湤楽を特に日

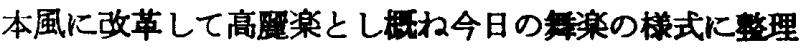
した。この外前述の神楽歌など我が国古来からの歌は 主として宮中の神事や㦈式に用いられた後には催馬楽。 朗詠などの謡物む加えられた（伊业神宮ではこれらを彻 神楽と呼び里神楽と区別している). しかし応仁の乱後 戦乱が続き京の楽人む四散，衰徽の一途をたどり，武家 が式楽を能楽としてからは一堆衰えた. 徳川時代に入り

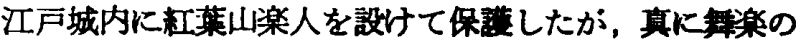
中心が東京に移つたのは明治 3 年太政官の中に雅泉局が 設直されてからである.

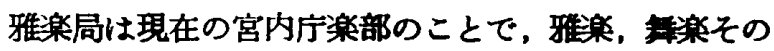
他古典楽などの伝承保存と谈素を行つている．以上は日

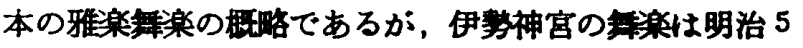

年产内庁から派生したものであり，従つて現在伝えてい る50 数曲は，曲目，様式とも宮内庁楽部と略々同じで

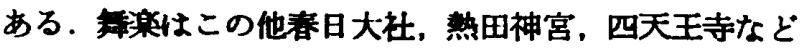
各所で行われているが門の恰人（楽人）が圆かれてい ろのは宮内庁染部之伊㐞神宮のみである。

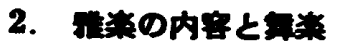

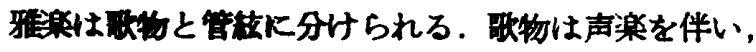

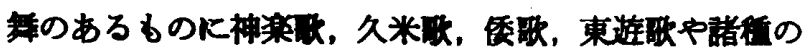
国卧などがあり，年いるのには催馬楽，朗詠，その 他風俗歌や古来からの国栖人の政がある．神楽歌などに

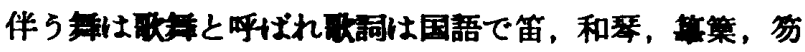

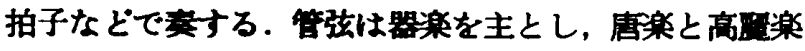

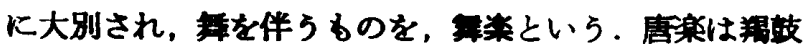

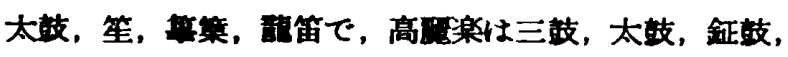
策，高震笛で读秦する。

\section{3. 争养の国}

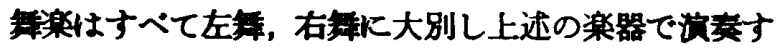
る.歌詞は用いず，仮面を用いるるのと用いないるのと

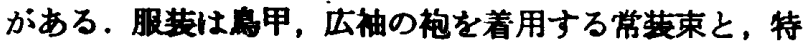

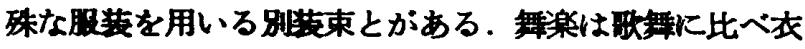

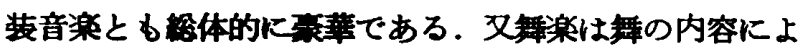

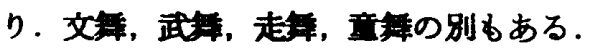

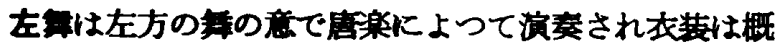

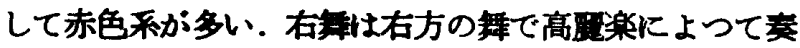
ろ、衣装は萠黄色系である。

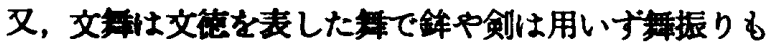
传美で落着きがある．武特倵徳武功を表現し而壮で武 具を持つて舞5．走非起とも云われ跳踓多くスピー

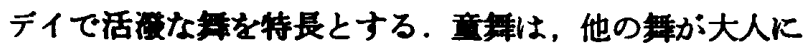
よつてなされるのに対し少年などによつて舞われるすの

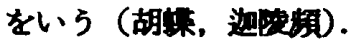

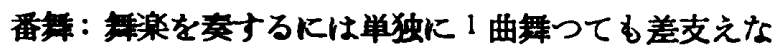
いが，普通左右 ${ }^{1}$ 曲ずつ组合せて演奏する。これを翻

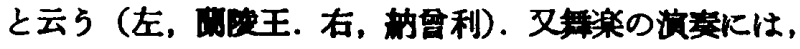

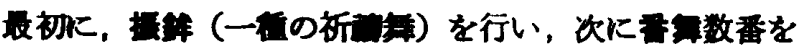

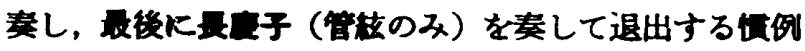
になつている. 